\title{
THE COMPLIANCE LEVEL OF OFFICIALS FOR STAFF DEVELOPMENT IN LAW ENFORCEMENT OF STATE CIVIL APPARATUS DISCIPLINE AT THE GOVERNMENT OF BENGKULU PROVINCE
}

\author{
By: \\ Agung Praja Putra, Iskandar, Jonny Simamora
}

\begin{abstract}
Government of Bengkulu Province is strongly committed to improve the quality of the bureaucratic reform of Apparatus Resourcesparticularly apparatus resources reform at the environment of Local Government of Bengkulu Province. Based on Attachment 1 of Regulation of the Head of the Civil Service Agency No. 21 of 2010 concerning the Implementing Regulations of Government Regulation No. 53 of 2010 on Discipline of Civil Servants, it is known that the employee dismissal procedures that violate discipline begins by calling the concerned continued with the establishment of inspection team. The results of the examination if proven to do violation, then the competent authorities impose disciplinary punishment. There have been many advances experienced by the government in the field of employment, which previously civil servants performance was rated based on patronage system where the presentation and work are preferred switched to merit systemin which the competence and performance of employees are preferred. However, there are still some violations occurred both violations of discipline and criminal.
\end{abstract}

Keywords: Compliance - Officials for Staff Development - Law Enforcement Discipline Violation - State Civil Apparatus 


\section{A. INTRODUCTION}

\section{Background of the Research}

State Civil Apparatus

Employees hereinafter will be

referred as ASN employees are employees who serve as the executor of public policy, public servant, and adhesives and unifying the nation, as stated in Article 10 of the Law of the Republic of Indonesia Number 5 of 2014 on State Civil Apparatus (ASN Law).

ASN assignments had been regulated in Article 11 of ASN Law which stated that ASN employees are in charge of: a. Implementing public policy made by the Officials for Staff Development in accordance with the provisions of the legislation; $b$. Providingqualified and professional public services; and c. Strengthening the unity and integrity of the Unitary State of Republic of Indonesia.

In order to carry out their duties, violations frequently occurred that may disrupt public services which should be prioritized in carrying out their duties. As civil servants and employees of public certainly ASN employees who areoriginally civil servants at the time appointed as civil servants are required to take an oath/pledge, violation of duty and/or oath/pledge of civil servants is a common disciplinary offense.

Based on the information from Regional Employment Board, it was known that as many as 36 people are convicted of Corruption, where as many as 13 people have been discharged and 23 people have not been dismissed as a civil servant in accordance with the provisions of the legislation in force, namely Government Regulation No. 53 of 2010 on Discipline of Civil Servants which remains valid to the time of this study.

Government Regulation No. 11 of 2017 on the Civil Servant Management is also the implementing regulation of the ASN Law. Thus both government regulations can be used as guidelines in law enforcement against violations of discipline by the ASN in the Government of Bengkulu Province.

In Article 229 paragraph (3) and (4) of Government Regulation No. 11 of 2017 on the Civil Servant Management explicitly mentioned that:

(3) Civil servants with disciplinary offenses are sentenced to discipline. 
(4) The punishment of discipline referred to in paragraph (3) was dropped by officials who are authorized to give punishment.

Based on the background above, the author interested in discussing the issue in the form of a thesis entitled: "The Compliance Level of Officials for Staff Development in Law Enforcement of State Civil Apparatus Discipline at the Government of Bengkulu Province".

\section{Identification of Problem}

The problem issued in this journal was: How was the Compliance Level of Officials for Staff Development in Law Enforcement of State Civil Apparatus Discipline at the Government of Bengkulu Province?

\section{B. RESEARCH METHOD}

The research method used was empirical research. This type of research was field research because the studied object was the object in the field. Approach method used was empirical approach which is better known as sociological method that is besides conducting empirical research by doing interview also studying books, journals and previous research result and all existing regulations.

\section{RESULTS AND DISCUSSION}

The Compliance Level of Officials for Staff Development in Law Enforcement of State Civil Apparatus Discipline at the Government of Bengkulu Province

Regional Employment Boardis a supporting element of the Governor's duties, led by a Head who works under and responsible to the Governor through the Regional Secretary. Provincial Regional Employment Board has the main duty to conduct the preparation and implementation of regional policies in the field of regional personnel apparatus. ${ }^{1}$

In Article 4 paragraph (1) of Bengkulu Governor Regulation No. 66 of 2016 concerning Position, Organizational Structure, Duties and Functions, and Working Procedures of the Regional Employment Board of Bengkulu Province, it is stated that "the Head of the Board has the duty to implement the drafting and

\footnotetext{
${ }^{1}$ Anonymous, Rencana Strategis Badan Kepegawaian Daerah Provinsi Bengkulu Tahun 2016- 2021, Regional Employment Board of Bengkulu Province, Bengkulu, 2016, p. 7.
} 
implementation of regional policies in the field of regional personnel apparatus". 2

In the Provincial Government of Bengkulu, the problem of regional personnel is managed by the Regional Employment Board of Bengkulu Province, which is a Regional Apparatus Organization that was formed specifically to handle the affairs of the Bengkulu Provincial employment. The objective formulated by the Regional Employment Board of Bengkulu Province in carrying out its employment management is "Increased professionalism of the Apparatus" in Bengkulu Province as expected.

In Article 362 of Government Regulation No. 11 of 2017 on the Management of Civil Servants, it is stated that "At the time this Government Regulation comes into force, it is revoked and declared invalid a number of Government Regulations and mandates the establishment of a new Government

\footnotetext{
${ }^{2}$ Article 4 paragraph (1) of Bengkulu Governor Regulation No. 66 of 2016 concerning Position, Organizational Structure, Duties and Functions, and Administration of Regional Employment Board of Bengkulu Province.
}

Regulation as a regulation of its implementation. ${ }^{3}$

In parallel to that, a number of Regulations are also stated to be valid as long as they have not been replaced based on Government Regulation No. 11 of 2017. This is stated in Article 363 of Government Regulation No. 11 of 2017 on the Management of Civil Servants. ${ }^{4}$

Some Regulations revoked and declared to be null and void are: Government Regulation Number 4 Year 1966 regarding Dismissal / Temporary Dismissal of Civil Servants as long as concerning provisions relating to civil servants; Government Regulation No. 21/1975 on Oaths/Pledges of Civil Servants; Government Regulation Number 24 Year 1976 regarding Civil Servant Leave; Government Regulation No. 15/1999 on the List of Rank of Civil Servants; Government Regulation Number 32 Year 1979 concerning Dismissal of Civil Servants, as amended several times, most recently by Government Regulation Number

\footnotetext{
${ }^{3}$ Article 362 of Government Regulation Number 11 Year 2017 on the Management of Civil Servants ${ }^{4}$ Article 363 of Government Regulation Number 11 Year 2017 on the Management of Civil Servants
} 
19 Year 2013 regarding Fourth Amendment to Government Regulation Number 32 Year 1979 concerning Dismissal of Civil Servants; Government Regulation No. 16 of 1994 on the Functional Position of Civil Servants; Government Regulation Number 29 of 1997 concerning Civil Servants Occupying Multiple Positions; Government Regulation Number 97 of 2000 on Formation of Civil Servants; Government Regulation Number 98 of 2000 on Procurement of Civil Servants; Government Regulation No. 99 of 2000 on the Rank of Civil Servants; Government Regulation Number 100 of 2000 concerning the Appointment of Civil Servants in Structural Positions; Government Regulation Number 101 Year 2000 on Education and Training of Civil Servants; Government Regulation No. 13 of 2001 on the Transfer of Status of Members of the Indonesian National Army and Members of the Indonesian Police Force into Civil Servants to occupy a Structural position; Government Regulation Number 9 Year 2003 on the Authority to Appoint, Transfer and
Dismiss Civil Servants; and Government Regulation No. 21 of 2014 on Dismissal of Civil Servants Achieving Retirement Age Limit for Functional Officials.

One Government Regulation which is not revoked and declared still in effect is Government Regulation Number 53 Year 2010 concerning Civil Service Discipline. Accordingly, Article 230 of Government Regulation No. 11 of 2017 concerning the Management of Civil Servants states that "Further provisions regarding the performance appraisal of civil servants and civil servant discipline as referred to in Article $228^{5}$ and Article $229^{6}$ shall be

${ }^{5}$ Article 228 of Government Regulation Number 11 Year 2017 on the Management of Civil Servants, states that "(1) Assessment of the performance of civil servants aims to ensure the objectivity of civil servant development based on achievement system and career system. (2) Assessment of civil servants performance is based on performance planning at the individual level and unit level or organization, taking into account the targets, achievements, outcomes, and benefits achieved, and the behavior of civil servants. (3) The performance appraisal of civil servants is conducted objectively, measurable, accountable, participatory, and transparent. (4) The performance assessment of civil servants as referred to in paragraph (3) shall be conducted by the direct superior of PNS or officials determined by PyB."

${ }^{6}$ Article 229 of Government Regulation Number 11 Year 2017 on the Management of Civil Servants, states that "(1) To ensure the maintenance of order in 
regulated by Government

also guided by Government Regulation".

Since the Government Regulation regulating the performance appraisal and civil servant discipline as stipulated in Article 228 and Article 229 of Government Regulation Number 11 Year 2017 concerning Civil Servant Management has not yet been established, it is understood that for the enforcement of the discipline of State Civil Apparatus shall still be guided by Government Regulation No. 53 Year 2010 on Civil Servant Discipline. Article 6 of Government Regulation Number 53 Year 2010 concerning Civil Servant Discipline states that "Without prejudice to the provisions in the criminal legislation, civil servants who commit disciplinary offenses are sentenced to discipline. The problem arises if the PPPK who commits a disciplinary offense whether the disciplinary enforcement which is

the smooth implementation of duties, civil servants are required to comply with the discipline of civil servants. (2) Government Institutions are obliged to carry out disciplinary enforcement of civil servants and carry out various discipline improvement efforts. (3) Civil servants who commit disciplinary offenses are sentenced to discipline. (4) The disciplinary punishment as referred to in paragraph (3) shall be imposed by the competent authorities."

Regulation No. 53 of 2010 on Civil Service Discipline, needs further study.

In accordance with the duties and functions as a support element of the task of the Governor of Bengkulu in the implementation of government tasks and development, especially in the field of employment, Regional Employment Board of Bengkulu Province has always been strongly committed to implementing a change of paradigm of human resources management that emphasized the rights and obligations of individual employees to new perspective of strategic human resource management in order to always be available the resources of the Civil State Apparatus (ASN) that is in line with the dynamics of changes in the ASN mission and the vision and mission of the Governor in the Regional Medium Term Development Plan (RPJMD) of Bengkulu Province. Therefore, RPJMD of Bengkulu Province Year 2016-2021 used as guidance in the preparation of Strategic Plan for Regional Employment Board of Bengkulu Province in 2016-2021. 
Related to the implementation of reformation of bureaucracy especially reformation of apparatus resources within the Regional Government of Bengkulu Province is in need of a change of employment management that is capable of supporting the development of democratic, decentralized and dynamic governance, and social market economy that is more open, so it needs to build Bengkulu Regional ASN that has higher strength and ability and competitiveness and more able to implement the achievement of the goals and programs of the Government and Local Government. Development and quality improvement of Human Resources Apparatus or ASN at this time is the main discussion both in the public and private sector. This is triggered due to various technological advances and knowledge as well as culture.

Based on the research results, it was obtained data from Regional Employment Board of Bengkulu Province about some ASN personnel who violate the discipline for being convicted in a criminal act of corruption, but only as many as 13 people who were sentenced to discipline as shown in Table 1 below:

Table 1. Civil Servants being Convicted of Criminal Acts of Corruption that Have/Have Not Been Dismissed

\begin{tabular}{|c|c|c|c|c|}
\hline $\mathrm{NO}$ & $\begin{array}{c}\text { NAME OF } \\
\text { CONVICTED }\end{array}$ & LEVEL & $\begin{array}{c}\text { COUR } \\
\mathrm{T} \\
\text { RULIN } \\
\mathrm{G}\end{array}$ & DESC. \\
\hline 1 & $\begin{array}{l}\text { Muhammad Ali } \\
\text { Afni, S.Sos. }\end{array}$ & $\begin{array}{c}\text { III / } \\
\mathrm{d}\end{array}$ & $\begin{array}{c}\text { March } \\
\text { 20, } \\
2012\end{array}$ & Not yet \\
\hline 2 & $\begin{array}{l}\text { Rahmat Eka } \\
\text { Wijaya, S.T. }\end{array}$ & $\begin{array}{c}\text { III / } \\
\mathrm{c}\end{array}$ & $\begin{array}{c}\text { August } \\
16, \\
2013\end{array}$ & Not yet \\
\hline 3 & $\begin{array}{l}\text { Ir. Moch. } \\
\text { Karyamin }\end{array}$ & $\begin{array}{c}\mathrm{III} / \\
\mathrm{d}\end{array}$ & $\begin{array}{c}\text { March } \\
18 \\
2015\end{array}$ & lready \\
\hline 4 & $\begin{array}{l}\text { Abu Hasan } \\
\text { Azhari, S.Pi. }\end{array}$ & $\begin{array}{c}\mathrm{III} / \\
\mathrm{c}\end{array}$ & $\begin{array}{c}\text { March } \\
27, \\
2015\end{array}$ & already \\
\hline 5 & $\begin{array}{l}\text { Ir. Bismalinda, } \\
\text { M.Si. }\end{array}$ & $\begin{array}{c}\text { IV / } \\
\text { a }\end{array}$ & $\begin{array}{l}\text { March } \\
27 \\
2015\end{array}$ & already \\
\hline 6 & $\begin{array}{l}\text { Sudirman, } \\
\text { S.Sos. }\end{array}$ & $\begin{array}{c}\mathrm{III} / \\
\mathrm{d}\end{array}$ & $\begin{array}{l}\text { April } \\
2015\end{array}$ & Not yet \\
\hline 7 & $\begin{array}{l}\text { Lukman } \\
\text { Haryanto, S.Pd. }\end{array}$ & $\begin{array}{c}\text { III / } \\
\text { d }\end{array}$ & $\begin{array}{c}14 \\
\text { April } \\
2015\end{array}$ & Not yet \\
\hline 8 & Drs. Almizan & $\begin{array}{c}\mathrm{IV} / \\
\mathrm{b}\end{array}$ & $\begin{array}{l}\text { May } \\
26, \\
2015\end{array}$ & Not yet \\
\hline 9 & $\begin{array}{l}\text { Adrianto Hima, } \\
\text { S.E. }\end{array}$ & $\begin{array}{c}\mathrm{III} / \\
\mathrm{c}\end{array}$ & $\begin{array}{c}\text { August } \\
24, \\
2015\end{array}$ & already \\
\hline 10 & $\begin{array}{l}\text { Edi Santoni, } \\
\text { S.Sos., M.Kes. }\end{array}$ & $\begin{array}{c}\text { IV / } \\
\mathrm{a}\end{array}$ & $\begin{array}{l}\text { Octobe } \\
\text { r } 26, \\
2015\end{array}$ & already \\
\hline 11 & $\begin{array}{l}\text { Dr. Ir. } \\
\text { Herawansyah, }\end{array}$ & $\begin{array}{c}\mathrm{IV} / \\
\mathrm{c}\end{array}$ & $\begin{array}{c}\text { June } \\
14,\end{array}$ & Not yet \\
\hline
\end{tabular}




\begin{tabular}{|c|c|c|c|c|}
\hline & M.Sc., M.T. & & 2016 & \\
\hline 12 & Ir. Fatmawati & $\begin{array}{c}\mathrm{IV} / \\
\mathrm{a}\end{array}$ & $\begin{array}{c}\text { Septem } \\
\text { ber } 7 \\
2016\end{array}$ & already \\
\hline 13 & $\begin{array}{l}\text { Bambang } \\
\text { Herwan, S.Sos., } \\
\text { S.T. }\end{array}$ & $\begin{array}{c}\mathrm{III} / \\
\mathrm{d}\end{array}$ & $\begin{array}{c}\text { Septem } \\
\text { ber 7, } \\
2016\end{array}$ & Not yet \\
\hline 14 & Jawawi, S.T. & $\begin{array}{c}\mathrm{III} / \\
\mathrm{d}\end{array}$ & $\begin{array}{c}16 \\
\text { Septem } \\
\text { ber } \\
2016\end{array}$ & already \\
\hline 15 & $\begin{array}{l}\text { Yenni Arfianti, } \\
\text { B.P.A. }\end{array}$ & $\begin{array}{c}\mathrm{III} / \\
\mathrm{b}\end{array}$ & $\begin{array}{c}28 \\
\text { Septem } \\
\text { ber } \\
2016\end{array}$ & already \\
\hline 16 & Safri, S.Sos. & $\begin{array}{c}\mathrm{III} / \\
\mathrm{d}\end{array}$ & $\begin{array}{c}29 \\
\text { Septem } \\
\text { ber } \\
2016\end{array}$ & Not yet \\
\hline 17 & $\begin{array}{ll}\text { Ir. } & \text { Rinaldi, } \\
\text { M.M. } & \end{array}$ & $\begin{array}{c}\mathrm{IV} / \\
\mathrm{c}\end{array}$ & $\begin{array}{l}\text { Octobe } \\
\text { r 14, } \\
2016\end{array}$ & already \\
\hline 18 & $\begin{array}{l}\text { Maryani Devi, } \\
\text { S.Sos. }\end{array}$ & $\begin{array}{c}\mathrm{III} / \\
\mathrm{c}\end{array}$ & $\begin{array}{c}\text { Decem } \\
\text { ber 20, } \\
2016\end{array}$ & already \\
\hline 19 & Amrullah, S.P. & $\begin{array}{c}\text { IV / } \\
\text { a }\end{array}$ & $\begin{array}{c}25 \\
\text { Novem } \\
\text { ber } \\
2016\end{array}$ & Not yet \\
\hline 20 & $\begin{array}{l}\text { Deni Setiawan, } \\
\text { S.P., M.Si. }\end{array}$ & $\begin{array}{c}\mathrm{III} / \\
\mathrm{c}\end{array}$ & $\begin{array}{c}25 \\
\text { Novem } \\
\text { ber } \\
2016\end{array}$ & Not yet \\
\hline 21 & Soneta Efendi & $\mathrm{II} / \mathrm{a}$ & $\begin{array}{c}25 \\
\text { Novem } \\
\text { ber } \\
2016\end{array}$ & Not yet \\
\hline 22 & Khairul Anwar & $\begin{array}{c}\mathrm{III} / \\
\mathrm{b}\end{array}$ & $\begin{array}{c}25 \\
\text { Novem } \\
\text { ber } \\
2016\end{array}$ & Not yet \\
\hline 23 & Deri Antoni & $\begin{array}{c}\mathrm{III} / \\
\mathrm{c}\end{array}$ & $\begin{array}{c}25 \\
\text { Novem } \\
\text { ber } \\
2016\end{array}$ & Not yet \\
\hline 24 & $\begin{array}{l}\text { Lilik Sukirman, } \\
\text { S.P. }\end{array}$ & $\begin{array}{c}\mathrm{III} / \\
\mathrm{d}\end{array}$ & $\begin{array}{c}25 \\
\text { Novem }\end{array}$ & Not yet \\
\hline
\end{tabular}

\begin{tabular}{|c|c|c|c|c|}
\hline & & & $\begin{array}{c}\text { ber } \\
2016\end{array}$ & \\
\hline 25 & Ir. Edi Nevian & $\begin{array}{c}\text { IV / } \\
\text { d }\end{array}$ & $\begin{array}{c}25 \\
\text { Novem } \\
\text { ber } \\
2016\end{array}$ & Not yet \\
\hline 26 & $\begin{array}{l}\text { BuyungMutaha } \\
\text { n, S.T. }\end{array}$ & $\begin{array}{c}\mathrm{III} / \\
\mathrm{d}\end{array}$ & $\begin{array}{c}\text { March } \\
20, \\
2017\end{array}$ & already \\
\hline 27 & Untung, S.T. & $\begin{array}{c}\mathrm{III} / \\
\mathrm{c}\end{array}$ & $\begin{array}{c}\text { March } \\
20, \\
2017\end{array}$ & already \\
\hline 28 & $\begin{array}{l}\text { Ismilianto, } \\
\text { M.Pd. }\end{array}$ & $\begin{array}{c}\mathrm{IV} / \\
\mathrm{a}\end{array}$ & $\begin{array}{c}\text { July 4, } \\
2017\end{array}$ & Not yet \\
\hline 29 & Junaidi H., S.T. & $\begin{array}{c}\mathrm{IV} / \\
\mathrm{a}\end{array}$ & $\begin{array}{c}\text { July } \\
25, \\
2017\end{array}$ & Not yet \\
\hline 30 & Edi Efendi, S.E. & $\mathrm{II} / \mathrm{a}$ & $\begin{array}{c}\text { August } \\
29, \\
2017\end{array}$ & Not yet \\
\hline 31 & $\begin{array}{l}\text { Andi } \\
\text { Roslinsyah, } \\
\text { S.T., M.T. }\end{array}$ & $\begin{array}{c}\mathrm{IV} / \\
\mathrm{b}\end{array}$ & $\begin{array}{c}11 \\
\text { Septem } \\
\text { ber } \\
2017\end{array}$ & Not yet \\
\hline 32 & $\begin{array}{l}\text { Delpi } \\
\text { Pardiansyah }\end{array}$ & $\begin{array}{c}\mathrm{III} / \\
\mathrm{c}\end{array}$ & $\begin{array}{c}\text { Decem } \\
\text { ber } 12, \\
2017\end{array}$ & Not yet \\
\hline 33 & $\begin{array}{l}\text { Hendri } \\
\text { Sumantri, A.M. } \\
\text { KL. }\end{array}$ & $\begin{array}{c}\mathrm{III} / \\
\mathrm{d}\end{array}$ & $\begin{array}{c}\text { Decem } \\
\text { ber 23, } \\
2017\end{array}$ & already \\
\hline 34 & Sahril, S.T. & $\begin{array}{c}\mathrm{III} / \\
\mathrm{d}\end{array}$ & $\begin{array}{l}\text { Januar } \\
\text { y } 24, \\
2018\end{array}$ & Not yet \\
\hline 35 & Aprianti, S.E. & $\begin{array}{c}\mathrm{III} / \\
\mathrm{d}\end{array}$ & $\begin{array}{l}\text { Januar } \\
\text { y } 29 \\
2018\end{array}$ & Not yet \\
\hline 36 & $\begin{array}{ll}\text { Tamimi } & \text { Lani, } \\
\text { S.T. } & \end{array}$ & $\begin{array}{c}\mathrm{IV} / \\
\mathrm{a}\end{array}$ & $\begin{array}{l}\text { March } \\
5,2018\end{array}$ & Not yet \\
\hline
\end{tabular}

Data Source: Regional Employment Board of Bengkulu Province on $20^{\text {th }}$ of March to $20^{\text {th }}$ of April 2018 (processed)

Based on the Presidential Decree Number 53 Year 2014 on the 
Granting of Proxy to the Head of the National Employment Boardon behalf of the President to Establish Promotion, Dismissal and Giving Retirement for Civil Servants Ranked as the Junior Administrator of Level IV/c Upward, the President delegated his authority to the Head of the NationalEmployment Board to dismiss civil servants of level IV/c and above who violate the discipline of ASN, but with the issuance of Letter of Head of NationalEmployment Board stating that the authority of dismissal of Civil Servant of Provincial Region is to Provincial Official for Staff Development namely Governor, then Governor is fully responsible in terminating ASN of Provincial government.

Based on the data of discipline violations mentioned above, it is known as many as 36 people are convicted cases of Corruption, where as many as 13 people have been dismissed and 23 people have not been dismissed as civil servants. Dismissal of 13 civil servants below was starting from baperjakat session until the issuance of the governor's decision about the dismissal has been run as it should. Based on thetrialbaperjakatwas proven to violate the discipline, it will be recommended for termination.

Based on Attachment 1 of the Regulation of the Head of the National Employment Board Number 21 of 2010 concerning the Regulation of the Implementation of Government Regulation No. 53/2010 concerning Civil Servant Discipline, it is known that the procedure of dismissing employees violating discipline begins by calling the concerned followed by the formation of the examining team. The results of the examination if proven to be a violation, then the authorized officials have right to give sentence to discipline.

Based on the results of the study, there were 13 people who were dismissed and 23 people who have not been dismissed, if grouped, it can be seen those that has been dismissed in Table 2 below:

Table 2. Civil Servants Violating Discipline at Provincial Government of Bengkulu (Already Dismissed)

\begin{tabular}{|c|c|c|c|c|}
\hline $\mathrm{NO}$ & $\begin{array}{c}\text { NAME OF } \\
\text { CONVICTED }\end{array}$ & LEVEL & $\begin{array}{l}\text { COURT } \\
\text { RULING }\end{array}$ & KET \\
\hline 1 & $\begin{array}{l}\text { Ir. Moch. } \\
\text { Karyamin }\end{array}$ & $\begin{array}{c}\mathrm{III} / \\
\mathrm{d}\end{array}$ & $\begin{array}{c}\text { March 18, } \\
2015\end{array}$ & $\begin{array}{l}\text { alrea } \\
\text { dy }\end{array}$ \\
\hline
\end{tabular}




\begin{tabular}{|c|c|c|c|c|}
\hline 2 & $\begin{array}{l}\text { Abu Hasan } \\
\text { Azhari, S.Pi. }\end{array}$ & $\begin{array}{c}\mathrm{III} / \\
\mathrm{c}\end{array}$ & $\begin{array}{c}\text { March 27, } \\
2015\end{array}$ & $\begin{array}{l}\text { alrea } \\
\text { dy }\end{array}$ \\
\hline 3 & $\begin{array}{l}\text { Ir. Bismalinda, } \\
\text { M.Si. }\end{array}$ & $\begin{array}{c}\mathrm{IV} / \\
\mathrm{a}\end{array}$ & $\begin{array}{l}\text { March 27, } \\
2015\end{array}$ & $\begin{array}{l}\text { alrea } \\
\text { dy }\end{array}$ \\
\hline 4 & $\begin{array}{l}\text { Adrianto } \\
\text { Himawan, S.E. }\end{array}$ & $\begin{array}{c}\mathrm{III} / \\
\mathrm{c}\end{array}$ & $\begin{array}{c}\text { August 24, } \\
2015\end{array}$ & $\begin{array}{l}\text { alrea } \\
\text { dy }\end{array}$ \\
\hline 5 & $\begin{array}{l}\text { Edi Santoni, } \\
\text { S.Sos., M.Kes. }\end{array}$ & $\begin{array}{c}\mathrm{IV} / \\
\mathrm{a}\end{array}$ & $\begin{array}{c}\text { October 26, } \\
2015\end{array}$ & $\begin{array}{l}\text { alrea } \\
\text { dy }\end{array}$ \\
\hline 6 & Ir. Fatmawati & $\begin{array}{c}\text { IV / } \\
\text { a }\end{array}$ & $\begin{array}{c}\text { September } \\
7,2016\end{array}$ & $\begin{array}{l}\text { alrea } \\
\text { dy }\end{array}$ \\
\hline 7 & Jawawi, S.T. & $\begin{array}{c}\text { III / } \\
\text { d }\end{array}$ & $\begin{array}{c}16 \\
\text { September } \\
2016\end{array}$ & $\begin{array}{l}\text { alrea } \\
\text { dy }\end{array}$ \\
\hline 8 & $\begin{array}{l}\text { Yenni Arfianti, } \\
\text { B.P.A. }\end{array}$ & $\begin{array}{c}\mathrm{III} / \\
\mathrm{b}\end{array}$ & $\begin{array}{c}28 \\
\text { September } \\
2016\end{array}$ & $\begin{array}{l}\text { alrea } \\
\text { dy }\end{array}$ \\
\hline 9 & $\begin{array}{ll}\text { Ir. } & \text { Rinaldi, } \\
\text { M.M. } & \end{array}$ & $\begin{array}{c}\mathrm{IV} / \\
\mathrm{c}\end{array}$ & $\begin{array}{c}\text { October 14, } \\
2016\end{array}$ & $\begin{array}{l}\text { alrea } \\
\text { dy }\end{array}$ \\
\hline 10 & $\begin{array}{l}\text { DeviMaryani, } \\
\text { S.Sos. }\end{array}$ & $\begin{array}{c}\mathrm{III} / \\
\mathrm{c}\end{array}$ & $\begin{array}{c}\text { December } \\
20,2016\end{array}$ & $\begin{array}{l}\text { alrea } \\
\text { dy }\end{array}$ \\
\hline 11 & $\begin{array}{l}\text { BuyungMutaha } \\
\text { n, S.T. }\end{array}$ & $\begin{array}{c}\text { III / } \\
\text { d }\end{array}$ & $\begin{array}{c}\text { March 20, } \\
2017\end{array}$ & $\begin{array}{l}\text { alrea } \\
\text { dy }\end{array}$ \\
\hline 12 & Untung, S.T. & $\begin{array}{c}\mathrm{III} / \\
\mathrm{c}\end{array}$ & $\begin{array}{c}\text { March 20, } \\
2017\end{array}$ & $\begin{array}{l}\text { alrea } \\
\text { dy }\end{array}$ \\
\hline 13 & $\begin{array}{l}\text { Hendri } \\
\text { Sumantri, A.M. } \\
\text { KL. }\end{array}$ & $\begin{array}{c}\text { III / } \\
\text { d }\end{array}$ & $\begin{array}{c}\text { December } \\
23,2017\end{array}$ & $\begin{array}{l}\text { alrea } \\
\text { dy }\end{array}$ \\
\hline
\end{tabular}

Data Source: Regional Employment

Board of Bengkulu Province on $20^{\text {th }}$ of March to $20^{\text {th }}$ of April 2018 (processed)

According to the Regulation of the Head of NationalEmployment BoardNumber 21 of 2010 and Presidential Decree No. 53 of 2014, the process of dismissing the 13 convicted corruptors is to summon the concerned, then form the Examining Team. If based on the results of the examination proved to violate the discipline, then the
Governor dismissed the 12 convicted persons and proposed the dismissal of one person convicted on behalf of Ir. Rinaldi, M.M. level IV/c, based on Presidential Decree Number 53 Year 2014 for civil servants class IV/c and above dismissed by the Head of NationalEmployment Boardon behalf of the President.

Article 247 of Government Regulation No. 11 of 2017 concerning the Management of Civil Servants, states "Civil Servants may be dismissed with respect or not dismissed as punishable by imprisonment based on a court decision having a permanent legal force for committing a criminal act with a minimum imprisonment of 2 (two) years and the criminal committed unplanned".

Article 87 Paragraph (4) SubParagraph $b$ of the ASN Law which determines in principle the civil servant is dismissed with no respect due to imprisonment or confinement based on a court decision with permanent legal force for committing a crime of offense or offenses related to position and/or public crime.

The implementation of Article 87 Paragraph (4) Sub-Paragraph b of 
the ASN Law should be implemented for civil servants who are sentenced to imprisonment based on a court decision with permanent legal force for committing a criminal offense or criminal offense relating to a position shall be dismissed with no respect regardless of duration of becoming the civil servant was sentenced to prison.

According to Article 6 of Government Regulation Number 53 Year 2010 concerning Civil Servant Discipline should not exclude criminal verdict, civil servants who violate discipline are sentenced to discipline. This means that the Officials for Staff Development of Bengkulu Province can impose disciplinary punishment in addition to the criminal punishment that has been decided by the Court.

Judging from the research data, most disciplinary offenses are due to violation of discipline due to being convicted of corruption crime cases and others violate discipline in the form of absence to work, but in this study only studied the violation of discipline due to corruption case convict.

A total of 23 people who have not been dismissed, the mechanism based on Head of NationalEmployment Board Regulation No. 21 of 2010 and Letter of Head of NationalEmployment Board Number: K.26-30/V.105-3/99 is by summoning the convicted, then form the Examining Team. If based on inspection results proved to violate the ASN discipline, then the 23 persons are dismissed by the Governor.

From the 13 people dismissed there was one person filing a lawsuit to the State Administrative Court of Bengkulu on behalf of Ir. Fatmawatilevel IV/a which according to the Regulation of the Head of the NationalEmployment Board, the dismissal is done by Officials for Staff Development of Bengkulu Province. Ir. Fatmawati filed a lawsuit against the Governor of Bengkulu as Official for Staff Development of Bengkulu Province, but her lawsuit was rejected, so the process of dismissal as a civil servant did not experience any obstacles at all.

Judging from the research data, most disciplinary offenses are due to violation of discipline due to being 
convicted of corruption crime cases and others violate discipline in the form of absence to work, but this study only studied in violation of discipline due to corruption case convict.

A total of 23 people who have not been dismissed, the mechanism based on Head of NationalEmployment Board Regulation No. 21 of 2010 and Letter of Head of NationalEmployment Board Number: K.26-30/V.105-3/99 is by summoning the convicted, then form the Examining Team. If based on inspection results proved to violate the ASN discipline, then the 23 persons are dismissed by the Governor.

Judging from the names of civil servants who have and have not been dismissed, then most of those who have not been dismissed is a violation of corruption.

The fact that the Provincial Government of Bengkulu is a shelter for corruption inmates from regencies/cities in Bengkulu Province such as RahmatEkaWijaya, Dr. Herawansyah, M.Sc., M.T., and others, where Dr. Herawansyah, M.Sc. M.T. previously was a civil servant in the Municipal Government of Bengkulu, then moved to the Government of Seluma Regency, and eventually joined the Provincial Government of Bengkulu.

Then based on the research results it is known that one of the detainees is known as the civil servant in the Bureau of Development Administration of Regional Secretariat of Bengkulu Province who is also Treasurer for Grants Election Fund of Regional Head/Regional Deputy Head of 2010, namely Muhammad Ali Afni, S. Sos. NIP. 197906222002121004 and has run criminal penalties, but not sentenced to discipline in the form of dismissal as civil servants by Officials for Staff Development. This was revealed from the lawsuit of one civil servant in the Office of Marine and Fisheries of Bengkulu Province, namely Ir. Fatmawati NIP. 196305011992032005 to the State Administrative Court of Bengkulu against the Governor of Bengkulu, where Ir. Fatmawati was sentenced by the Governor of Bengkulu for committing criminal corruption in the Class IIB Women's Prison of Bengkulu. 
Article 247 of Government Regulation No. 11 of 2017 concerning the Management of Civil Servants, states "Civil Servants may be dismissed with respect or not dismissed as punishable by imprisonment based on a court decision having a permanent legal force for committing a criminal act with a minimum imprisonment of 2 (two) years and the criminal committed unplanned".

Article 87 Paragraph (4) SubParagraph $b$ of the ASN Law which determines in principle the civil servant is dismissed with no respect due to imprisonment or confinement based on a court decision with permanent legal force for committing a crime of offense or offenses related to position and/or public crime.

The implementation of Article 87 Paragraph (4) Sub-Paragraph b of the ASN Law should be implemented for civil servants who are sentenced to imprisonment based on a court decision with permanent legal force for committing a criminal offense or criminal offense relating to a position shall be dismissed with no respect regardless of duration of becoming the civil servant was sentenced to prison.

Based on the letter of the Head of the NationalEmployment Board, as many as 23 unpunished persons occupying the positions of JPT Utama, JPT Madya, and JF Ahli Utama are not available to the Provincial Government of Bengkulu. They occupy positions of:

a) JPT pratama;

b) $J A$;

c) JF ahlimadya, JF ahlimuda, and JF pratama; and

d) supervisor JF, proficient JF, skilled JF, and beginner JF.

Thus it can be understood that the authority to dismiss 23 civil servants who violate the discipline of being convicted of corruption case is absolutely in the hands of Officials for Staff Development of Provincial Governor of Bengkulu. The governor has the authority to impose disciplinary sentences on the 23 civil servants.

Based on the number of civil servants who have been sentenced as many as 13 people and who have not been punished as many as 23 people, then it can be put on the table the degree of compliance as follows:

Table 3. Percentages, degrees, and 
categories of compliance of Officials for Staff Development of Bengkulu Province

\begin{tabular}{|c|c|c|c|}
\hline $\begin{array}{c}\text { TOTAL } \\
\text { OF } \\
\text { CONVI } \\
\text { CTED } \\
\text { (dismisse } \\
\text { d) }\end{array}$ & $\begin{array}{c}\text { PERCEN } \\
(\boldsymbol{\%})\end{array}$ & $\begin{array}{c}\text { DEG } \\
\text { REE }\end{array}$ & $\begin{array}{c}\text { ORY } \\
\text { OREG }\end{array}$ \\
\hline 0 to 17 & 0.00 to & Low & Disobedi \\
& 47.22 & & ent \\
\hline $18-26$ & 50.00 to & Moder & $\begin{array}{c}\text { Less } \\
\text { adherent }\end{array}$ \\
\hline $27-36$ & 75.00 to & High & $\begin{array}{c}\text { Submissi } \\
\text { ve }\end{array}$ \\
\hline
\end{tabular}

Description: Deviation Standard $=00.01$

Source: Soerjono

Soekanto,

Kesadaran Hukum dan

Kepatuhan

Hukum,

Directorate of Higher

Education Department of

Education and Culture and

Faculty of Law University of Indonesia, Jakarta, 1977 (modified)

Based on Table 3 above, it can be understood that the degree of compliance of Officials for Staff Development of BengkuluProvince is included in the Low category/ Incompliance in running the existing regulations.

Based on Table 3 above, it can be understood that the degree of compliance of Officials for Staff Development of BengkuluProvince is included in the Low category/ Incompliance in running the existing regulations.However, in this case the reality on the field there are other views, such as stated by the Head of the Regional Employment Board of Bengkulu Province (IrDiahIrianti, M.Si): "ASN who got the case of Corruption should at that time also dismissed it means the rule is unfair". Then from the Assistant of General Administration of the Provincial Secretariat of Bengkulu (H. GotriSuyanto, SE, M. Soc.Sc): "Not un-dismissed, but still awaiting the ongoing process based on the results of the Baperjakat meeting and through the Approval of Officials for Staff Development."

Based on the results of interviews with two resource persons (Assistant III and Head of Regional Employment Board of Bengkulu Province), it is understood that the consideration to not dismiss civil servants who commit disciplinary offenses is a humanitarian consideration, but in accordance with the data and facts that some of them 
have been dismissed and some have not, therefore there is lawsuit to the State Administrative Court. Based on document studies conducted there is data that the process of dismissal is running, it just the matter of time.

Thus, based on the results of interviews with two resource persons above, it can be understood that the Officials for Staff Development of BengkuluProvince not obedient in upholding the ASN discipline at the Provincial Government of Bengkulu.

\section{CLOSING}

\section{Conclusion}

Based on the
researchresults and
discussion, it is concluded
that the Officials for Staff
Development
BengkuluProvince who in
this case was the Governor of
Bengkulu has not been
obedient (low) in upholding
the law against violations of
ASN discipline in the
Provincial Government of
Bengkulu. This can be seen
from 36 violators who were
subject to sanctions, only 13
people / 33.33\% were
sentenced to discipline

punishment in the form of dismissal with respect-not on their own request and disrespectful dismissal as civil servants, which was less than $50 \%$.

\section{Suggestion}

It is suggested to the Officials for Staff Development or Responsible Officialsto comply with the Civil Servant Discipline Regulations and other regulations applicable in enforcing the law against violations committed by ASN at the Provincial Government of Bengkulu.

\section{REFERENCES}

Anonymous, Rencana Strategis Badan Kepegawaian Daerah Provinsi Bengkulu Tahun 20162021, Regional Employment Board of Bengkulu Province, Bengkulu, 2016.

Bengkulu Governor Regulation No. 66 of 2016 concerning Position, Organizational Structure, Duties and Functions, and Administration of Regional Employment Board of Bengkulu Province.

Government Regulation Number 11 Year 2017 on the Management of Civil Servants 